\title{
Developing Android Based - Student Worksheet Using Guided Inquiry Model to Improve Science Process Skill on Human Reproduction System Material, Grade XI of Senior High School (SMA)
}

\author{
$1^{\text {st }}$ Ermayanti Sutiyo \\ Yogyakarta State University, Yogyakarta, Indonesia \\ ermawyanti_sutiyo@yahoo.com
}

\author{
$2^{\text {nd }}$ Djukri \\ Yogyakarta State University, Yogyakarta, Indonesia \\ djukri@uny.ac.id
}

\begin{abstract}
This research aims to (1) Produce android based student's worksheet with Guided Inquiry model to improve the learning process of human reproduction system materials that are suitable for high school students of grade XI, (2) To analyze the effectiveness of the application of the android based learning with guided inquiry model of human reproduction system to improve science process skill of high school students of grade XI, (3) to know the improvement of science process skill of high school student of grade XI during learning process by using android-based worksheet with Guided Inquiry model in human reproduction system.
\end{abstract}

The development procedure of this research refers to the steps of the procedural model adapted from the Richey and Klein Design and Development Research (D \& DR) model that includes: (1) model development phase, (2) model internal validation, (3) model external validation, and (4) model use. The try outs were conducted on eleventh grade students of SMA N 1 Sewon, Bantul Regency. A limited try outs were conducted on eleventh grade students of MIPA 2 involving 20 students and field try outs were conductedon eleventh grade students of MIPA 1 and MIPA 6 involving in total of 60 students. The data were collected using LKPD validation instrument, science process skill measurement test, and science process skill observation sheet.

The result of the research shows that: (1) Application of android-based student's worksheetwith Guided Inquiry model on human reproduction system material evaluated from the assessment on feasibility aspects of material, appearance, language and reliability included in good category, (2) Application of student's worksheet based on android with guided inquiry model on reproduction system material is considered effective, (3) Android-based student's worksheetwith Guided Inquiry model in this research known to be able to improve the skills of students' science process.

Keywords - student worksheets, android, guided inquiry, science process skills, human reproduction system

\section{INTRODUCTION}

In the learning process, when the object of learning can not be studied directly then the need for a medium and teaching materials so that objects or phenomena can still be learned by learners. According to Arsyad (2002: 4) "learning media includes tools that are physically used to convey the content of the subject matter, which among other things consist of books, tape recorders, tapes, films, drawings, and others". In other words, the media is a component of learning resources or physical targets that contain instructional materials in a student environment that can stimulate students to learn in their knowledge.

The material of the human reproductive system is a biological material that studies a system that takes place in the human body that takes place physiologically in the human body. This material examines everything related to the human reproductive system. Most of the material about the human reproductive system is classified as a material that is difficult for students to understand if it is only conveyed by lecturing or oral method of the teacher, besides the material of the human reproduction system is a material that can not be observed by naked eye, it needs media and materials teach to learn it so that learners can understand it well.

One of the teaching materials that can help learners to study the reproductive system in humans is the learner activity sheet (LKPD). Trianto (2008: 148) suggests the activity sheet of learners is a guide for learners who are used to conduct investigation and problem solving activities. LKPD is not an activity sheet that contains only material summaries and exercises to be done by students. But LKPD can be a guide for developing cognitive aspects as well as for developing all aspects of learning in the form of experimental and demonstration guides (Trianto, 2007: 73).

In general, LKPD is a learning tool as a complement or supporting means of implementation of Learning Implementation Plan and LKPD is one of the tools in learning. This is in accordance with the opinion of Majid 
(2007: 12) which explains LKPD is a sheet contains the task of instructions and steps to complete a task to be done by learners. Similarly, Darmojo \& Kaligis (1992: 40) explained that LKPD can make it easier for teachers to manage the learning process by changing learning conditions from teacher centered learning to student centered learning, helping teachers to direct learners find the concepts through their own activities or within the working group, and facilitate the teacher to monitor the success of learners to achieve the learning objectives LKPD is very well used to promote the learners in order to learn well used in the application of guided methods or to provide development training.

Along with the development of the era, the information and communication technology (ICT) also developed even has encouraged the creation of innovations in all fields. One area that continues to develop is the field of education marked by the birth of the concept of Electronic Learning (e-Learning), but perceived e-learning is still lacking because it is limited by certain places and facilities. Responding to these problems, then developed learning by utilizing mobile and mobile-based mobile media (mobile) or better known as mobile learning that promises independence of time and place in the real sense (Riyanto, 2006: 387).

Mobile devices used in mobile learning include PDAs, mobile phones, laptops, and tablet PCs. The characteristics of this mobile device have a high degree of flexibility that allows learners to access materials, direction and information related to learning whenever and wherever. This will increase the attention of learners on learning materials (Yuniati, 2011: 94). This can be utilized by teachers to transform teaching materials in the form of LKPD mobile.

One of the fastest growing mobile devices today is the smartphone. Smartphones are widely circulated today is mostly based android smartphone. Android is a superior system and also a leader on various mobile platforms (Gandhewar, 2010; Neha, 2014: 272). As reported by Okezone techno that by the end of 2015 is estimated there are about 55 million smartphone users in Indonesia. Along with that ertumbuh also internet users in Indonesia, because the average user access using mobile devices such as android smartphone.

Based on observations and interviews at SMA N 1 Banguntapan and SMA N 1 Sewon Bantul, that the school has facilities and infrastructure that support to do learning by using android based mobile learning devices. Facilities and adequate infrastructure is the availability of wifi networks and the majority of learners who have android smartphone.

The development of LKPD of mobile learning learning based on learning using android must be in accordance with the nature of science so that the application of learning model that is relevant to the nature of science is needed as a science in the form of facts, concepts, theories and generalizations that describe nature and science as a process that emphasizes learning directly through observation.

One of the learning models relevant to the nature of science is the inquiry learning model. Inquiry learning model is a core part of contextual based learning activities. The knowledge and skills acquired by the students are expected not the result of remembering a set of facts, but the result of finding themselves. Teachers should always design activities that refer to the activity of finding, regardless of the material being taught, (Trianto: 2012: 114).

Inquiry learning is designed to invite students directly into the scientific process into a relatively short time. The results of Schlenker's research, in Joyce and Weil (1992: 198), suggest that inquiry training can improve understanding of science, be productive in creative thinking, and students become skilled in obtaining and analyzing information. The inquiry applied in the learning process can improve students' ability to observe and express answers to problems through interpretation of data until a conclusion is obtained (Carlson, 2008: 33).

In this study, researchers used guided inquiry instructional model. The guided inquiry instructional model is one part of the inquir method, which in the guided inquiry model (teacher guided inquiry) has an active role in determining the problem and the stages of the solution. With this approach learners learn more oriented to guidance and instruction from the teacher until students can understand the concepts of the lesson. Teachers act only as facilitators, while learners develop their ability to engage in the discovery of concepts through maximum teacher guidance.

The use of guided inquiry instructional model in this study as the basis for the preparation of LKPD is expected to train the students to be more independent in learning and also can train the ability of students' learning process.

The ability of the scientific process is a skill gained from the exercise of fundamental mental, physical and social abilities as a driver of higher abilities. The basic skills that have been developed and trained over time will become a skill, while the process skill approach is a way of looking at students as a whole person. This way of viewing is described in teaching and learning activities paying attention to the development of knowledge, attitudes, values, and skills. All three elements are united in one individual and skilled in the form of creativity, Hariwibowo, et al. (2009).

Based on observations, $90 \%$ of the operating system on mobile phones used by SMAN 1 Sewon, Bantul-based Android students, but their use in learning is still not maximal. In addition, from the results of interviews with teachers note that the material of human reproductive system requires a deeper understanding because it is quite complicated. This is evidenced by $80 \%$ of learners say matari is difficult to understand compared with other materials. This material requires a strong understanding so that, required a representative learning media and can be repeated whenever and wherever when learners need. Also the media that can encourage learners to find their own concepts with guided steps that exist on the media learning.

Based on the above exposure, the authors are interested to examine the problem in the thesis entitled: "Development of Mobile Learning Based Learning Worksheet with Inquiry Learning Model to Improve Skills of Science Process of Class XI Students on Human Circulation System Material".

\section{METHOD}

This research and development using Design Development Research method. Design and Development Research is a systematic study of design, development and evaluation processes with the aim of establishing empirical 
foundations for creating instructional and non-instructional products to enhance the development of newly developed tools and models (Richey and Klein, 2008). Design and Development Research is a type of inquiry for the field of Instructional Design and Technology (IDT) dedicated to creating new knowledge and validation exercises from existing ones. Based on these definitions IDT field facilitates learning and improves performance by creating, using and managing in accordance with instructional and non-instructional interventions (Richey and Klein, 2014).

In science, design and development must be bound by an understanding built on replicated empirical research. Models and procedures must be validated. Solutions from existing problems are supported by data. Researchers believe that the reality in the field is insufficient to apply empirical methods in facilitating our understanding of design and development processes. The research needs in particular with respect to the models and processes applied by designers and developers. Some of the models, design strategies, and tools used in practice are empirically tested and validated. This is a gap for research design and development research in overcoming the problem.

Design and Development Research covers a wide spectrum of activities and interests. This includes the study of overall design and development processes, processes of particular components or the specific impact of design and development efforts. Such research may involve situations where one studies the despair and development of others. However, it can also involve situations in which a person undertakes design and development activities and learns the process at the same time. Both cases have the distinction between design and development and the process.

Numaker et al. (1991) in Ellis and Levy (2010) identifies five points in the design and development research, among others: a) establishing a conceptual framework, b) developing an architectural system, c) analyzing and designing systems, d) creating prototypes and e) test and evaluate prototype. Numaker et al. (1991) in Ellis and Levy (2010) identifies five points in the design and development research, among others: a) establishing a conceptual framework, b) developing an architectural system, c) analyzing and designing systems, d) creating prototypes and e) test and evaluate prototype. Peffers et al. (2007) expanded the previous identification, Nunamaker et al. (1991) and Hevner et al. (2004) developed a six model.

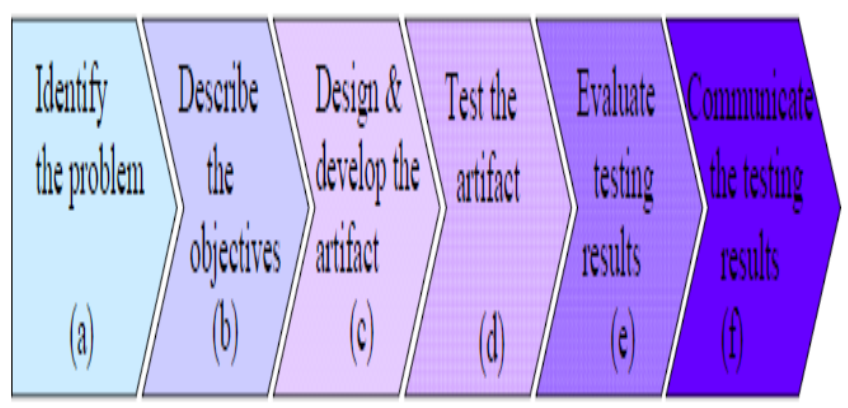

Gambar 2. six stages of the Design and Development Research process (Ellis and Levy, 2010)

\section{RESULTS AND DISCUSSION}

The result of research data obtained in this study is the result of observation of science process skill during learning process, and cognitive learning result in the form of pretest and posttest value obtained from experimental class and control class. Provision of pretest problems at the beginning of the sbeleum given the treatment aims to see the initial knowledge and readiness of learners both in the experimental class and in the control class. Then in the class that has been determined as an experimental class which will be replaced by treatment in both classes.

In the reproduction system material, class XI IPA 3 as experimental class and class XI IPA 2 as control, which in this material reproduction system is 2 (two) meetings whose activities are adjusted to the syntax of the learning model used and the control class in accordance with activities that have been prepared by the biology teacher at SMAN 1 Sewon Bantul on the implementation plan of learning.

After the learning activities are implemented, then given posstest at each end of learning activities on reproduction system material is finished, it aims to see how far the influence of learning media used in learning activities.

\section{CONCLUSION}

Based on research and analysis of data that has been done then it can be concluded that:

1. The worksheet of the android-based learner with guided inquiry model on human reproduction system material is feasible to be used to improve the science process skill of the learner

2. Sheets based on android learner with guided inquiry model on material of human reproduction system effective to be applied as medium of learning at Class XI SMA

The Android based learner's worksheet with guided inquiry model can improve the science process skill in human reproduction system material.

\section{REFERENCES}

[1] Arsyad, A. (2009) . Media Pembelajaran. Jakarta: Rajawali Pres

[2] Majid, A (2007). Perencanaan pembelajaran: Mengembangkan standar kopetensi guru. Bandung: PT. Remaja Rosda Karya

[3] Riyanto 2006: 387, Riyanto, Bambang, Muh. Tamimuddin H Sri Widayati. 2006. Perancangan Aplikasi M-Learning Berbasis Java. Prosiding Konferensi Nasional Teknologi Informasi \& Komunikasi untuk Indonesia. Bandung: Institut Teknologi Bandung

[4] Yuniati, Lukita. 2011. Pengembangan Media Pembelajaran Mobile Learning Efek Dopp;er Sebagai Alat Bantu Dalam Pembelajaran Fisika yang Menyenangkan. JP2F. Volume 2 Nomor 2 September. 92-101

[5] Gandhewar, N., \& Sheikh, R. (2010). Google Android: An Emerging Software Platform For Mobile Device. International Journal on Computer Science and Enginering, 12, 0975-3397. 
[6] Nada, Shofwatun. 2015. Tesis: Pengembangan Lembar Kerja Peserta Didik (LKPD) Berbasis Problem Based Learning untuk Meningkatkan Berpikir Kritis, Karakter Peduli Lingkungan, dan Pemahaman Konsep Peserta Didik Kelas X MA Ali Maksum Yogyakarta. Yogyakarta. Universitas Negeri Yogyakarta.

[7] Handayani, Farida. 2015. Tesis: Pengembangan Multimedia Pembelajaran Biologi Berbasis Android Materi interaksi dalam Ekosistem untuk Meningkatkan Kemandirian Belajar dan Hasil Belajar Kognitif Siswa Kelas X SMA. Universitas Negeri Yogyakarta.
[8] Siqid, Ahmad. 2017. Pengembangan Modul Pembelajaran Biologi Materi Ekosistem Air Tawar Berbasis Android dengan Model Problem Based Learning Untuk Meningkatkan Kemampuan Berfikir Kreatif Peserta Didik SMA Kelas X. Yogyakarta. Universitas Negeri Yogyakarta.

[9] Richey, R. C., and Klein, J. D. (2007). Design and Development Research: Methods, Strategies and Issues. Mahwah, NJ: Lawrence Erlbaum Associates. 